DOI: https://doi.org/10.24127/ajpm.v9i4.3009

\title{
PENGARUH SELF REGULATED LEARNING DAN WEB COURSE BERBANTUAN GOOGLE CLASSROOM, WHATSAPP GROUP TERHADAP PEMAHAMAN KONSEP
}

\author{
Sofri Rizka Amalia ${ }^{*}$, Dian Purwaningsih ${ }^{2}$ \\ $1^{1 * 2}$ Universitas Peradaban, Bumiayu, Jawa Tengah, Indonesia \\ ${ }^{*}$ Corresponding author \\ E-mail: $\quad$ sofri.rizkia@gmail.com ${ }^{1)}$ \\ dian.purwaningsih24@yahoo.com $^{2)}$
}

Received 02 August 2020; Received in revised form 21 November 2020; Accepted 12 December 2020

\begin{abstract}
Abstrak
Penelitian ini bertujuan untuk mengetahui pengaruh self regulated learning terhadap pemahaman konsep, pengaruh e-learning tipe Web Course berbantuan google classroom dan whatsapp group terhadap pemahaman konsep, dan pengaruh self regulated learning dan e-learning tipe Web Course berbantuan google classroom dan whatsapp group terhadap pemahaman konsep. Penelitian ini tergolong dalam penelitian Quasi ekperimen tipe One group posttest only design. Subjek penelitian ini adalah mahasiwa semester IV sejumlah 17 mahasiswa program studi pendidikan matematika Universitas Peradaban. Pengumpulan data penelitian ini adalah observasi, tes, dan angket. Sedangkan analisis data yang digunakan adalah uji regresi dengan aplikasi SPSS. Hasil penelitian ini adalah terdapat pengaruh positif antara penerapan e-learning berbantuan google classroom dan whatsapp group terhadap kemampuan pemahaman konsep, terdapat pengaruh positif antara self regulated learning terhadap kemampuan pemahaman konsep, dan terdapat pengaruh positif antara self regulated learning dan penerapan $e$ learning berbantuan google classroom dan whatsapp group terhadap kemampuan pemahaman konsep.
\end{abstract}

Kata kunci: E-learning; Google Classroom; Pemahaman Konsep; self regulated learning; Web centric Course; Whatsapp Group.

\begin{abstract}
This study aims to determine the effect of self-regulated learning on concept understanding, the effect of e-learning type of Web Course assisted by google classroom and Whatsapp group on concept understanding, and the effect of self regulated learning and e-learning type of Web Course assisted by google classroom and Whatsapp group on understanding concept. This research belongs to the Quasi type One group posttest only design experiment. The subject of this research is the fourth semester students of the mathematics education study program at the University of Civilization. The research data collection was observation, test and questionnaire. While the data analysis used is a regression test with the SPSS application. The results of this study are that there is a positive influence between the implementation of e-learning assisted by google classroom and Whatsapp group on the ability to understand concepts, there is a positive influence between self regulated learning on the ability to understand concepts, and there is a positive influence between self regulated learning and the application of e-learning assisted by google classroom and Whatsapp group for the ability to understand concepts.
\end{abstract}

Keywords: E-learning; Google Classroom; Concept Understanding; self regulated learning; Web centric Course; Whatsapp Group.

This is an open access article under the $\underline{\text { Creative Commons Attribution } 4.0 \text { International License }}$

\section{PENDAHULUAN}

Indonesia merupakan salah satu negara yang terkena pandemi
Coronavirus Disease (Covid-19). Tahun 2019, Oleh karena itu, Mendikbud mengeluarkan surat edaran nomor 4 
Tahun 2020 yang berisi kebijakan pelaksanaan proses belajar dirumah dengan pembelajaran daring/ jarak jauh (2020). Dengan Pembelajaran Jarak Jauh (PJJ) diharapkan dapat membuat siswa tetap belajar dan mengurangi penyebaran virus.

Permasalahan di lapangan menunjukkan bahwa kemampuan pemahaman konsep siswa masih kurang. Hal ini diperkuat hasil survei bahwa mahasiswa kurang aktif sehingga hanya beberapa mahasiswa yang dapat meningkat kemampuannya dalam memahami masalah (Putri et al., 2019). Dalam pembelajaran jarak jauh mempunyai kendala sehingga hasil yang diperoleh kurang maksimal (Arifa, 2020). Hasil survei lain menunjukkan bahwa di SMA Titian Teras Jambi terdapat $18 \%$ siswa yang tidak berani bertanya dikelas, sehingga pemahaman materinya kurang (Kurniahayati \& Syamsurizal, 2012). Hasil uji insvestigasi awal penelitian lain di Taruna Pekanbaru menunjukkan bahwa $75,68 \%$ siswa mempunyai nilai tes kemampuan pemahaman konsep dibawah KKM yaitu 75 (Muhandaz et al., 2018). Hasil observasi di SMP Negeri 13 Cirebon menunjukkan bahwa pembelajaran bersifat teacher centre sehingga siswa kurang aktif, tidak memiliki pemahaman konsep yang diberikan dan rata-rata hasil belajar masih dibawah KKM (Hidayat et al., 2017).

Berdasarkan beberapa pendapat ahli dapat disimpulkan bahwa pemahaman konsep merupakan kemampuan dasar matematika yang digunakan untuk menyelesaikan situasi baru. Indikator pemahaman konsep yang digunakan adalah kemampuan menyatakan ulang konsep yang diterima, mengelompokkan objek-objek sesuai sifat-sifatnya, menyebutkan contoh dan bukan contoh dari konsep, merepresentasikan konsep dalam bentuk gambar, grafik, tabel dan lain - lain, mengkaji syarat perlu dan cukup sebuah konsep, memilih prosedur yang digunakan, menggunakan konsep dalam menyelesaikan masalah kehidupan sehari-hari (Sari, 2017).

Hal ini diperkuat dengan beberapa hasil penelitian. Penelitian di SMP 13 Cirebon menunjukkan bahwa terdapat hubungan positif antara penggunaan software e-learning dengan pemahaman konsep dan mengalami peningkatan sebesar 71,9 \% (Hidayat et al., 2017). Penelitian lain menunjukkan bahwa penerapan media online efektif terhadap kemampuan pemahaman konsep siswa dan $93,33 \%$ siswa tuntas (Suryawan \& Permana, 2020). Arifin \& Herman menghasilkan bahwa terdapat pengaruh E-learning model web centric course terhadap pemahaman konsep dan kemandirian belajar (2018). Hasil lain menunjukkan bahwa melalui penerapan e-learning, kemampuan pemahaman konsep siswa mencapai $75,81 \%$ (Juniati et al., 2020). Berdasarkan hasil penelitian terdahulu terlihat bahwa penggunaan e-learning dapat meningkatkan kemampuan pemahaman konsep.

Kebaruan yang dilakukan dalam penelitian ini adalah penggunaan jenis e-learning web coures dan berbantuan google classroom dan whatsapp group. Google classroom adalah aplikasi online yang digunakan untuk mengumpulkan tugas, pemberian materi, mengevaluasi tugas yang tidak terkikat waktu dan tempat (Putri et al., 2019). Sedangkan whatsapp merupakan aplikasi yang digunakan sebagai alat komunikasi yang berisi pesan teks, gambar, video, dokumen, audio, dan panggilan suara (Kusuma, 2020). whatsapp juga memiliki fitur whatsapp 
group yang dapat digunakan untuk membuat grup sesuai dengan mata kuliah masing-masing sehingga dapat terhubung dengan teman satu kelas dan dosen.

Selain pemilihan model pembelajaran yang tepat, Self Regulated Learning/ kemandirian belajar mempunyai peran penting dalam pembelajaran online di masa pandemi covid-19. Kemandirian belajar adalah kesadaran diri sendiri untuk belajar secara mandiri tanpa bantuan orang lain dan bertanggung jawab atas hasil yang akan dicapai (Yuliati \& Saputra, 2020). Dengan kemandirian belajar yang baik mahasiswa dapat memahami dan menyelesaikan permasalahan yang diberikan. Indikator Self Regulated Learning/ kemandirian belajar ada 5 , yaitu inisiatif, percaya diri, disiplin, tanggung jawab, dan motivasi (Malenda et al., 2018).

Penerapan pembelajaran $e$ learning tipe web course berbantuan Google classroom dan whatsapp group diharapkan membangun Self Regulated Learning mahasiswa dan mengembangkan kemampuan pemahaman konsep mahasiswa. Selain itu, mahasiswa dapat memperoleh informasi dan materi yang dapat digunakan untuk belajar. Mahasiswa juga dapat berdiskusi untuk membahas konsep dan materi perkuliahan.

Berdasarkan permasalah tersebut, tujuan penelitian ini adalah mengetahui (1) pengaruh Self Regulated Learning terhadap kemampuan pemahaman konsep, (2) pengaruh penerapan $e$ learning tipe Web Course berbantuan google classroom dan whatsapp group terhadap kemampuan pemahaman konsep, dan (3) pengaruh Self Regulated Learning dalam penerapan e-learning tipe Web Course berbantuan google classroom dan whatsapp group terhadap kemapuan pemahaman konsep.

\section{METODE PENELITIAN}

Penelitian ini merupakan penelitian kuasi eksperimen dengan rancangan One group posttest only design. Penelitian jenis ini adalah penelitian eksperimen yang hanya melakukan evaluasi di akhir eksperimen (Hastjarjo, 2019).

Penelitian ini dilakukan dengan menerapkan e-learning tipe web course berbantuan google classroom dan whatsapp group pada mata kuliah statistika matematika. Saat pembelajaran dilakukan observasi ketercapaian model yang digunakan. Setelah dilakukan pembelajaran, mahasiswa diberikan tes kemampuan pemahaman konsep dan angket kemandirian belajar.

Subjek penelitian ini adalah mahasiwa semester VI program studi pendidikan matematika Universitas Peradaban yang berjumlah 17 mahasiswa. Variabel yang akan diukur adalah ketercapaian penerapan $e$ learning tipe Web Course berbantuan google classroom dan whatsapp group, kemampuan pemahaman konsep dan kemandirian belajar.

Pengumpulan data penelitian ini adalah observasi, tes, dan angket. Observasi dilakukan untuk mengetahui ketercapaian penggunaan model. Tes digunakan untuk mengetahui kemampuan pemahaman konsep. Tes berisi 5 soal yang disesuaikan dengan indikator. Setelah melakukan tes, mahasiswa diberi angket kemandirian belajar sesuai dengan indikator. Angket terdiri dari 30 pernyataan. Sebelumnya tes dan angket disebarkan, dilakukan uji validitas dan reliabilitasnya. Analisis yang digunakan adalah uji regresi dengan aplikasi SPSS. 
DOI: https://doi.org/10.24127/ajpm.v9i4.3009

\section{HASIL DAN PEMBAHASAN}

Pembelajaran dilaksanakan dengan e-learning tipe web course berbantuan google classroom dan whatsapp group. Dalam pembelajaran mahasiswa diberi kesempatan untuk membuat video presentasi sesuai permasalahan dan materi statistika matematika. Video di kirimkan melalui whatsapp group. Pembelajaran dimulai dengan mendiskusikan materi yang telah diberikan melalui video dan melakukan tanya jawab. Mahasiswa diberikan latihan soal dan menjawab soal dan dibahas secara online di whatsapp group. setelah itu mahasiswa diberikan tugas melalui Google classroom dan dikumpulkan sesuai waktu yang telah ditentukan.

Setiap pembelajaran dilakukan observasi keterlaksanaan pembelajaran dan setelah pembelajaran selesai dilakukan tes kemampuan pemahaman masalah dan pemberian angket kemandirian.

Sebelum diberikan kepada mahasiswa, tes dan angket diuji validitas dan reliabilitas. Hasil uji validasai menunjukkan bahwa 5 soal tes dan 30 butir angket valid. Uji reliabilitas menghasilkan soal tes dan angket juga yang realibel.

Setelah itu dilakukan analisis uji prasyarat yaitu uji normalitas. Hasil uji normalitas dapat dilihat pada Tabel 1.

Tabel 1. Tests of Normality.

\begin{tabular}{lccc}
\hline & \multicolumn{3}{c}{ Kolmogorov-Smirnov $^{a}$} \\
\cline { 2 - 4 } & Statistic & df & Sig. \\
\hline $\begin{array}{l}\text { Pemahaman } \\
\text { konsep }\end{array}$ &, 197 & 17 &, 078 \\
\hline a. Lilliefors Significance Correction & \\
\hline
\end{tabular}

Berdasatkan hasil uji normalitas pada Tabel 1, nilai signifikansinya adalah 0,78 . Nilai signifikan $(0,78)$ lebih dari alpha $(0,05)$, sehingga dapat disimpulkan bahwa data berdistribusi normal

\section{Pengaruh Keterlaksanaan Pembelajaran terhadap Kemampuan Pemahaman Konsep.}

Setelah uji prasyarat terpenuhi, maka dilakukan uji regresi sederhana untuk mengetahui pengaruh keterlaksaan penerapan e-learning berbantuan google classroom dan whatsapp group. Data yang digunakan adalah data keterlaksanaan pembelajaran dan kemampuan pemahaman konsep. Uji regresi sederhana dilakukan menggunakan bantuan software SPSS 23.

Hipotesis uji regresi sederhananya adalah sebagai berikut.

Ho: Tidak terdapat pengaruh antara keterlaksanaan penerapan $e$ learning tipe web course berbantuan google classroom dan whatsapp group terhadap kemampuan pemahaman konsep.

$\mathrm{H} 1$ : terdapat pengaruh antara keterlaksanaan penerapan $e$ learning tipe web course berbantuan google classroom dan whatsapp group terhadap kemampuan pemahaman konsep.

Tabel 2. Anova keterlaksanaan model.

\begin{tabular}{cc}
\hline $\boldsymbol{F}$ & Sig. \\
\hline 36,121 & 0,000 \\
\hline
\end{tabular}

Berdasarkan hasil uji anova pada Tabel 2 terlihat bahwa nilai signifikaannya adalah 0,000 kurang dari 0,05 sehingga Ho ditolak. Jadi, dapat disimpulkan bahwa terdapat pengaruh antara penerapan e-learning berbantuan google classroom dan whatsapp group terhadap kemampuan pemahaman konsep.

Persamaan regresi dapat dilihat dari hasil coefficients pada Tabel 3. 
DOI: https://doi.org/10.24127/ajpm.v9i4.3009

Tabel 3. Coefficients.

\begin{tabular}{llc}
\hline & \multicolumn{2}{c}{$\begin{array}{c}\text { Unstandardizer } \\
\text { Coefficients }\end{array}$} \\
\cline { 2 - 3 } & \multicolumn{1}{c}{$\boldsymbol{B}$} & $\begin{array}{c}\text { Std. } \\
\text { Error }\end{array}$ \\
\hline (Costant) & 34,154 & 7,282 \\
Keterlaksanaan_model & 0,932 & 0,155 \\
\hline
\end{tabular}

Persamaan regresinya adalah $\hat{y}=34,154+0,932 x$. Terlihat bahwa koefisiennya positif sehingga dapat disimpulkan keterlaksanaan pembelajran berpengaruh positif terhadap kemampuan pemahaman konsep

Besarnya pengaruh dapat dilihat pada Tabel 4.

Tabel 4. Model summary keterlaksanaan model.

\begin{tabular}{ccccc}
\hline Model & $\boldsymbol{R}$ & $\begin{array}{c}\boldsymbol{R} \\
\text { Square }\end{array}$ & $\begin{array}{c}\text { Adjusted } \\
\boldsymbol{R} \text { Square }\end{array}$ & $\begin{array}{c}\text { Std. Error } \\
\text { of the } \\
\text { Estimate }\end{array}$ \\
\hline 1 &, $841^{\mathrm{a}}$ &, 707 &, 687 & 4,29318 \\
\hline
\end{tabular}

Terlihat bahwa nilai $R$ square-nya adalah 0,707 (Tabel 4). Hal ini berarti besarnya pengaruh antara keterlaksanaan penerapan e-learning tipe web course berbantuan google classroom dan whatsapp group terhadap kemampuan pemahaman konsep sebesar 70,7\%.

Hasil uji regresi sederhana tersebut sejalan dengan kondisi dilapangan. Pembelajaran menggunakan e-learning tipe web course google classroom dan whatsapp group dapat membuat mahasiswa lebih aktif dalam pembuatan video pembelajaran. Sehingga mereka lebih memahami materi yang akan mereka presentasikan. Hal ini lebih bermakna karena ketika mereka kurang memahami, mereka dapat mencari informasi agar lebih memahami materi tersebut. Saat diskusi di whatsapp group juga mahasiswa dapat mengembangkan kemampuan pemahaman konsepnya yaitu dengan mempelajarai video pembelajaran dan melakukan tanya jawab tentang materi yang diberikan. Kemampuan mahasiswa lebih terasah juga dengan mengerjakan tugas yang diberikan lewat aplikasi google classroom.

Hal tersebut diperkuat oleh beberapa hasil penelitian terdahulu. Hasil penelitian di SMP Negeri di Kota Singaraja menunjukkan bahwa terdapat pengaruh positif antara model blended learning berbantuan video animasi terhadap kemampuan pemecahan masalah dan pemahaman konsep siswa (Sudiarta \& Sadra, 2016). Penelitian lain menghasilkan terdapat pengaruh positif penerapan etnomatematika berbasis youtube menggunakan Corel Video Studio X10 terhadap kemampuan pemahaman konsep dan lebih baik daripada pembelajaran konvensioanal. Hasil lain menyebutkan terdapat peningkatan rata-rata nilai siswa melalui penerapan pembelajaran google classroom (Putri et al., 2019). Penerapan whatsapp dapat digunakan untuk meningkatkan hasil belajar siswa kelas X TBSM SMKN 4 Tasikmalaya.

\section{Pengaruh Kemandirian/Self Regulated Learning terhadap Kemampuan Pemahaman Konsep}

Data yang digunakan adalah data kemandirian belajar/ Self Regulated Learning. Hipotesis uji regresi sederhananya adalah sebagai berikut.

$\mathrm{H}_{0}$ : Tidak terdapat pengaruh antara Self Regulated Learning terhadap kemampuan pemahaman konsep.

$\mathrm{H}_{1}$ : terdapat pengaruh antara Self Regulated Learning terhadap kemampuan pemahaman konsep.

Hasil uji regresi sederhana adalah pada Tabel 5. 
DOI: https://doi.org/10.24127/ajpm.v9i4.3009

Tabel 5. Anova Self Regulated Learning

$\begin{array}{cc}\boldsymbol{F} & \text { Sig. } \\ 30,136 & 0,000\end{array}$

Dapat dilihat pada Tabel 5, nilai signifikannya adalah 0,000 kurang dari alpha $(0,05)$. Sehingga Ho ditolak artinya terdapat pengaruh antara Self Regulated Learning terhadap kemampuan pemahaman konsep.

Tabel 6. Coefficients Self Regulated Learning.

\begin{tabular}{lcc}
\hline & \multicolumn{2}{c}{$\begin{array}{c}\text { Unstandardizer } \\
\text { Coefficients }\end{array}$} \\
\cline { 2 - 3 } & $\boldsymbol{B}$ & Std. Error \\
\hline (Constant) & 23,683 & 7,282 \\
Kemandirian & 0,448 & 0,155 \\
\hline
\end{tabular}

Berdasarkan hasil pada Tabel 6 , persamaan regresinya adalah $\hat{y}=$ $23,683+0,448 x$. Terlihat bahwa koefisiennya positif sehingga dapat disimpulkan pengaruhnya positif antara self regulated learning terhadap kemampuan pemahaman konsep.

Besar pengaruhnya dapat dilihat dari Tabel 7.

Tabel 7. Model summary kemandirian.

\begin{tabular}{ccccc} 
Model & $\mathbf{R}$ & $\begin{array}{c}\mathbf{R} \\
\text { Square }\end{array}$ & $\begin{array}{c}\text { Adjusted } \\
\mathbf{R} \\
\text { Square }\end{array}$ & $\begin{array}{c}\text { Std. } \\
\text { Error of } \\
\text { the } \\
\text { Estimate }\end{array}$ \\
\hline 1 &, $817^{\mathrm{a}}$ &, 668 &, 646 & 4,56897 \\
\hline
\end{tabular}

Terlihat bahwa $R$ squarenya sebesar 0,668 (Tabel 7). Sehingga pengaruh self regulated learning terhadap kemampuan pemahaman konsep sebesar $66,8 \%$.

Hal tersebut sesuai dengan kenyataan di lapangan. Kemandirian mahasiswa lebih terasah dan terbentuk. Mahasiswa mengerjakan video sesuai dengan tugas masing-masing dikelompoknya. Hal ini dapat meningkatkan kemampuan pemahaman yang dimilikinya karena mempelajari sendiri dan mencari informasi sendiri. Mahasiswa juga secara mandiri menjawab latihan soal yang diberikan di whatsapp group. mahasiswa juga diberikan tugas secara individu dan secara mandiri menyelesaikannya sehingga lebih memahami konsep materi yang telah dipelajari saat pembelajaran.

Hasil penelitian ini sesuai dengan beberapa penelitian terdahulu. Pendekatan pembelajaran dan kemandirian berpengaruh terhadap kemampuan matematis (Fauzan, 2013). Hasil lain menyebutkan bahwa terdapat interaksi antara media pembelajaran dan kemandirian terhadap hasil belajar(Oktavera, 2015). Penelitian lain menunjukkan bahwa kemandirian belajar berkontribusi terhadap kemampuan pemahaman konsep matematika $(11,6 \%)$, terdapat kontribusi kecerdasan spasial dan kemandirian belajar terhadap kemampuan pemahaman konsep (42,8\%) (Mahayukti et al., 2015).

Pengaruh self regulated learning dan Keterlaksanaan Pembelajaran terhadap Kemampuan Pemahaman Konsep

Data yang digunakan adalah data hasil angket kemandirian belajar/ self regulated learning dan hasil keterlaksanaan penerapan e-learning tipe web course berbantuan google classroom dan whatsapp group dan hasil tes kemampuan pemahaman konsep. Analisis statistika yang digunakan adalah uji regresi ganda dengan bantuan SPSS 23.

Hipotesis uji regresi sederhananya adalah sebagai berikut.

$\mathrm{H}_{0}$ : Tidak terdapat pengaruh antara Self Regulated Learning dan keterlaksanaan penerapan $e$ - 
DOI: https://doi.org/10.24127/ajpm.v9i4.3009

learning tipe web course berbantuan google classroom dan whatsapp group terhadap kemampuan pemahaman konsep.

$\mathrm{H}_{1}$ : terdapat pengaruh antara Self Regulated Learning dan keterlaksanaan penerapan $e$ learning tipe web course berbantuan google classroom dan whatsapp group terhadap kemampuan pemahaman konsep.

Tabel 8. Anova X1 dan $X 2$.

\begin{tabular}{cc}
\hline $\boldsymbol{F}$ & Sig. \\
\hline 16,950 & 0,000 \\
\hline
\end{tabular}

Hasil uji regresi ganda disajikan pada Tabel 8, nilai signifikannya adalah 0,000 kurang dari alpha $(0,05)$, Ho ditolak. Jadi, dapat disimpulkan bahwa terdapat pengaruh antara Self Regulated Learning dan keterlaksanaan penerapan e-learning tipe web course berbantuan google classroom dan whatsapp group terhadap kemampuan pemahaman konsep.

Tabel 9. Coefficients $X 1$ dan $X 2$

\begin{tabular}{lll}
\hline & \multicolumn{2}{c}{$\begin{array}{c}\text { Unstandardizer } \\
\text { Coefficients }\end{array}$} \\
\cline { 2 - 3 } & \multicolumn{1}{c}{$\boldsymbol{B}$} & $\begin{array}{c}\text { Std. } \\
\text { Error }\end{array}$ \\
\hline (Constant) & 32,156 & 11,359 \\
Kemandirian & 0,067 & 0,286 \\
Keterlaksanaan_model & 0,802 & 0,579 \\
\hline
\end{tabular}

Persamaan regresi dapat dilihat pada Tabel 9. Persamaan regresi yang terbentuk adalah $\hat{y}=32,156+$ $0,067 x_{1}+0,802 x_{2}$ Terlihat bahwa koefisiennya positif sehingga terdapat pengaruh positif antara Self Regulated Learning dan keterlaksanaan penerapan e-learning tipe web course berbantuan google classroom dan whatsapp group terhadap kemampuan pemahaman konsep.
Tabel 10. Model Summary $X 1$ dan $X 2$

\begin{tabular}{ccccc} 
Model & $\boldsymbol{R}$ & $\begin{array}{c}\boldsymbol{R} \\
\text { Square }\end{array}$ & $\begin{array}{c}\text { Adjusted } \\
\boldsymbol{R} \text { Square }\end{array}$ & $\begin{array}{c}\text { Std. Error } \\
\text { of the } \\
\text { Estimate }\end{array}$ \\
\hline 1 &, $841^{\mathrm{a}}$ &, 708 &, 666 & 4,43514 \\
\hline
\end{tabular}

Besarnya pengaruh dapat dilihat pada Tabel 10, nilai $\mathrm{R}$ squarenya adalah 0,708 . Sehingga, besarnya pengaruh adalah $70,8 \%$.

Kenyataan dilapangan memperkuat hasil penelitian. Penerapan penerapan e-learning tipe web course berbantuan google classroom dan whatsapp group terlaksana dengan baik dan dapat membuat mahasiswa lebih mengembangkan kemampuan pemahaman konsep mahasiswa. Mahasiswa dilatih untuk memahami konsep saat pembuatan video pembelajaran, pemberian latihan dan tugas. Saat diskusi mahasiswa pun lebih memahami konsep yang diberikan dengan tanya jawab. Kemandirian mahasiswa juga terbentuk. Ketika membuat video mahasiswa mencari informasi secara mandiri, mengerjakan tugas dan latihan juga secara mandiri. Mahasiswa dapat lebih memahami materi sehingga pembelajaran lebih bermakna. Di masa pandemi covid-19, penerapan e-learning dan kemandirian belajar dapat mengembangkan kemampuan secara penuh karena mahasiswa diharuskan untuk aktif saat pembelajaran. Dengan pembelajaran online mahasiswa tetap memperoleh ilmu dan mengebangkan kemandirian dan kemampuanya.

Penelitian terdahulu memperkuat hasil yang diperoleh. Penerapan model PBL berbantuan e-learning dengan kemandirian mahasiswa unggul dan asor lebih baik daripada penerapan pembelajaran ekspositori (Saputra, 2017). Hasil lain menunjukkan bahwa terdapat pengaruh penerapan e-learning tipe web centric course terhadap 
pemahaman konsep dan kemandirian siswa (Arifin \& Herman, 2018). Penelitian lain menyebutkan bahwa terdapat hubungan signifikan antara pemanfaatan google classroom dan kemandirian terhadap hasil belajar mahasiswa (Ashadi \& Suhaeb, 2020).

Penelitian yang dilakukan mempunyai dampak yang positif terhadap pembelajaran. Pembelajaran menjadi lebih terstruktur dan dapat meningkatkan interaksi antar mahasiswa dan dosen. Dengan $e$ learning tipe web course berbantuan google classroom dan whatsapp group dapat mengembangkan kemampuan mahasiswa dalam menggunakan aplikasi pembelajaran.

\section{KESIMPULAN DAN SARAN}

Kesimpulan dalam penelitian ini adalah (1) terdapat pengaruh positif antara penerapan e-learning berbantuan google classroom dan whatsapp group terhadap kemampuan pemahaman konsep, (2) terdapat pengaruh positif antara self regulated learning terhadap kemampuan pemahaman konsep, dan (3) terdapat pengaruh positif antara self regulated learning dan penerapan $e$ learning berbantuan google classroom dan whatsapp group terhadap kemampuan pemahaman konsep.

Saran yang dapat berikan adalah (1) untuk penelitian selanjutnya bisa menggunakan model yang berbeda dan media online yang berbeda sehingga dapat meningkatkan kemampuan pemahaman konsep, (2) gunakan faktor lain yang dapat meningkatkan kemampuan pemahaman konsep.

\section{DAFTAR PUSTAKA}

Arifa, F. N. (2020). Tantangan Pelaksanaan Kebijakan Belajar dari Rumah dalam Masa Darurat Covid-19. Info Singkat, 12(7), 1318.
Arifin, F., \& Herman, T. (2018). Pengaruh Pembelajaran ELearning Model Web Centric Course terhadap Pemahaman Konsep dan Kemandirian Belajar Matematik. Jurnal Pendidikan Matematika, 12(2), 1-12.

Ashadi, N. R., \& Suhaeb, S. (2020). Hubungan Pemanfaatan Google Classroom dan Kemandirian terhadap Hasil Belajar Mahasiswa PTIK pada Masa Pandemi. Media Elektronik, 17(2), 46-51.

Hastjarjo, D. (2019). Rancangan Eksperimen-Kuasi QuasiExperimental Design. Buletin Psikologi, 27(2), 187-203. https://doi.org/10.22146/buletinpsi kologi.38619

Fauzan, A. (2013). Pengaruh Pendekatan RME dan Kemandirian Belajar Terhadap Kemamampuan Matematis Siswa. Semirata, 7-14.

Hidayat, R., Lusiyana, D., \& Mulyani, M. T. (2017). Kontribusi Penggunaan Software E-Learning Matematika SMP Versi 5.1. terhadap Peningkatan Pemahaman Konsep Matematis Siswa SMP pada Materi Geometri. Seminar Nasional Pendidikan Matematika 2017, 41-52.

Peraturan Pemerintah Republik Indonesia Nomor 21 Tahun 2020 Tentang Pembatasan Sosial Berskala Besar dalam rangka Percepatan Penangan Corona Virus Disease 2019, 1 (2019).

Juniati, A., Nindiasari, H., \& Khaerunnisa, E. (2020). Analisis Kemampuan Pemahaman Konsep Matematis Dan Karakter Siswa SMP dalam Pembelajaran ELearning. Wilangan, 1(2), 22-36.

Kurniahayati, D., \& Syamsurizal. (2012). Pengembangan

Pembelajaran Berbasis Web 
DOI: https://doi.org/10.24127/ajpm.v9i4.3009

Centric Course pada Materi Stoikiometri untuk Meningkatkan Minat Belajar Siswa di SMA Titian Teras Jambi. Edu-Sains, 1(1), 38-44.

Kusuma, J. W. (2020). Platform Whatsapp Group dan Webinar Zoom dalam Pembelajaran Jarak Jauh Pada Masa Pandemik Covid 19. Jurnal Ilmiah Pendidikan Matematika, 5(1), 97-106.

Mahayukti, G. ., Wibowo, D. ., \& Sadra, I. . (2015). Kontribusi Kecerdasan Spasial Dan Kemandirian Belajar Terhadap Pemahaman Konsep Matematika Siswa Sma Negeri Di Kecamatan Buleleng. Proceeding Seminar Nasional FMIPA UNDIKSHA V, 5(2), 168-177.

Malenda, T. O., Kadir, \& Suhar. (2018). Kemampuan Numerik Siswa SMP Pesisir Ditinjau dari Perbedaan Jenis Kelamin dan Kemandirian Belajar Siswa SMP Negeri 14 Kendari. Jurnal Penelitian Pendidikan Matematika, 6(3), 7184.

Surat Edaran Nomer 4 Tahun 2020 tentang Pelaksanakan Kebijakan Pendidikan dalam Masal Darurat Penyebaran Coronavirus Disease (covif-19), 1 (2020).

Muhandaz, R., Trisnawita, O., \& Risnawati. (2018). Pengaruh Model Pembelajaran Course Review Horay terhadap Kemampuan Pemahaman Konsep Matematis Berdasarkan Kemandirian Belajar Siswa SMK Pekanbaru. Juring: Journal for Research in Mathematics Learning, 1(2), 137-146.

Oktavera, S. (2015). Pengaruh Media Pembelajaran Dan Kemandirian Belajar Terhadap Hasil Belajar Ipa Siswa Kelas Iv Sekolah Dasar.
Jurnal Pendidikan Dasar, 6(2), 312.

https://doi.org/10.21009/jpd.062.13

Putri, G. K., Ani, Y., \& Dewi, S. (2019). Pengaruh Model Pembelajaran Jarak Jauh Berbasis Google Classroom Effect Of Google Classroom-Based Distance Learning Model. Al-Fikrah, 2(1), 60-79.

Saputra, J. (2017). Model Problem Based Learning Berbantuan E Learning terhadap Kemandirian Belajar Mahasiswa. KALAMATIKA, 2(2), 117-130.

Sari, P. (2017). Pemahaman Konsep Matematika Siswa pada Materi Besar Sudut Melalui Pendekatan PMRI. Jurnal Gantang, 2(1), 4150.

https://doi.org/10.31629/jg.v2i1.60

Sudiarta, I. G. P., \& Sadra, I. W. (2016). Pengaruh Model Blended Learning Berbantuan Video Animasi terhadap Kemampuan Pemecahan Masalah dan Pemahaman Konsep. Jurnal Pendidikan Dan Pengajaran, 49(2), 48-58.

Suryawan, I. P. P., \& Permana, D. (2020). Media Pembelajaran Online Berbasis Geogebra sebagai Upaya Meningkatkan Pemahaman Konsep Matematika. Prisma, 9(1), 108-117.

Yuliati, Y., \& Saputra, D. S. (2020). Membangun Kemandirian Belajar Mahasiswa Melalui Blended Learning di Masa Pandemi Covid19. Jurnal Elementaria Educasia, 3(1), 142-149. 